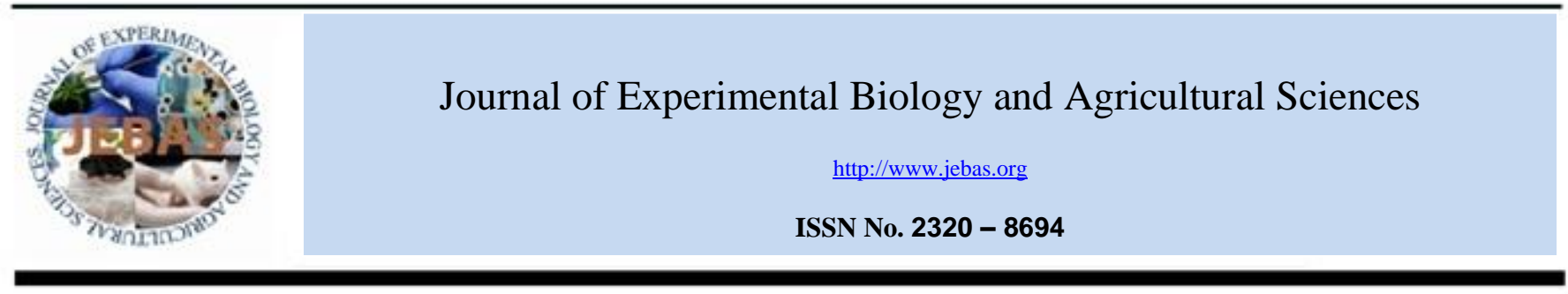

\title{
INFLUENCE OF ORGANIC AND MINERAL FERTILIZERS ON CHEMICAL AND BIOCHEMICAL COMPOUNDS CONTENT IN TOMATO (Solanum lycopersicum) VAR. MONGAL F1
}

\author{
Christophe DABIRE ${ }^{1}$, Abdoulaye SEREME $^{1, *}$, Charles PARKOUDA $^{2}$, Marius K. SOMDA ${ }^{3}$ and \\ Alfred S. TRAORE ${ }^{3}$
}

${ }^{1}$ Département Substances Naturelles/IRSAT/CNRST; 03 BP 7047 Ouagadougou 03; Burkina Faso

${ }^{2}$ Département Technologie Alimentaire/IRSAT/CNRST; 03 BP 7047 Ouagadougou 03; Burkina Faso

${ }^{3}$ Département de Biochimie-Microbiologie; Université Ouaga I Pr Joseph KI-ZERBO; 03 BP 7021 Burkina Faso

Received - July 19, 2016; Revision - August 11, 2016; Accepted - November 02, 2016

Available Online - November 13, 2016

DOI: http://dx.doi.org/10.18006/2016.4(Issue6).631.636

KEYWORDS
Tomato
Fertilization
Physical
Chemical and biochemical
characterizations

\begin{abstract}
The concentration of secondary metabolites can be influenced qualitatively and quantitatively by ecological factors and farming practices. The purpose of this study was to determine the impact of organic and mineral fertilization on physical characteristics and the content of chemical and biochemical compounds of the fruits of the tomato var. Mongal F1. Physical, chemical and biochemical characterizations of tomato samples were carried out from samples collected from control, organic and mineral fertilized plants, to assess the nutritional potential according to fertilization. Samples collected from the organic fertilizer had $\mathrm{pH}$ values of $4.21 \pm 0.01$ corresponding to measurable acidity of $8.47 \pm$ $0.06 \mathrm{~g}$ malic acid $/ 100 \mathrm{~g}$ Fresh Tomato (FT), dry matter of $4.18 \pm 0.02 / 100 \mathrm{~g}$ FT and total ash content of $0.38 \pm 0.01 / 100 \mathrm{~g}$ FT. The contents of fats, proteins are respectively $2.28 \pm 0.01$ and $0.70 \pm 0.02 \mathrm{mg} / 100 \mathrm{~g}$ FT, totals sugar value of $2.83 \pm 0.02 \mathrm{mg} / 100 \mathrm{~g}$ FT. For mineral fertilization, the samples had $\mathrm{pH}$ values of $4.16 \pm 0.01$ corresponding to a measurable acidity of $8.10 \pm 0.12 \mathrm{~g}$ malic acid $/ 100 \mathrm{~g}$ FT, values of dry matter $3.82 \pm 0.02 / 100 \mathrm{~g}$ FT and totals ash content of $0.37 \pm 0.01$. The contents of fats and proteins are respectively $0.27 \pm 0.01$ and $0.64 \pm 0.01 \mathrm{mg} / 100 \mathrm{~g}$ FT with totals sugar value of $2.56 \pm 0.01 \mathrm{mg} / 100 \mathrm{~g}$ FT. Result of study revealed that organic fertilization can increase the concentration of secondary metabolites production in tomato var. Mongal F1 than mineral fertilization. This increase may be probably due to the availability of various major and minor elements in organic fertilizer contrary to mineral fertilizer which has only three major elements, Nitrogen $(\mathrm{N})$, Phosphorus $(\mathrm{P})$ and Potassium (K). Globally fruit ripping has shown a positive effect on the accumulation of fats, proteins and total sugar.
\end{abstract}

\section{* Corresponding author}

E-mail: asereme@yahoo.fr (Abdoulaye SEREME)

Peer review under responsibility of Journal of Experimental Biology and Agricultural Sciences.

Production and Hosting by Horizon Publisher India [HPI] (http://www.horizonpublisherindia.in/).

All rights reserved.
All the article published by Journal of Experimental Biology and Agricultural Sciences is licensed under a Creative Commons Attribution-NonCommercial 4.0 International License Based on a work at www.jebas.org.

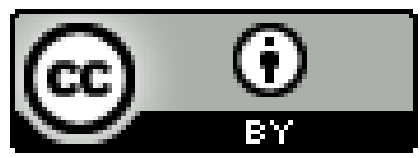




\section{Introduction}

Many epidemiological studies revealed the beneficial effects of fruit and vegetables on human health and avoiding chronic diseases such as cardiovascular disease including risk factors such as hypertension, diabetes, obesity and prevent also esophageal, stomach, pancreatic bladder and cervical cancers (Van Duyn \& Pivonka, 2000; Crawford et al., 1994; Oguntibeju et al., 2013). These studies demonstrated that fruits and vegetables have various nutrients such as carotenoids, phenolic compounds, vitamins, minerals, sulfur compounds which are associated with beneficial outcomes related to diseases cures (Wargovich, 2000; Chanforan, 2011). High consumption of tomatoes and tomato products have been associated with the reduction of carcinogenesis, especially prostate cancer and it may be due to the presence of lycopene, which give red color to the tomato (Giovannucci et al., 2002; Boileau 2003). Fruit contributes to a healthy and balanced diet rich in minerals (iron, phosphorus), vitamins $(\mathrm{C}, \mathrm{B})$, essential amino acids, sugars as well as dietary fiber (Chanforan, 2011). Further, Tohill et al. (2004) suggested that fruits and vegetable intake have positive effect on weight management and obesity prevention. The biochemical composition of tomato fruit varies according to the variety, environmental factors such as light, temperature, fertilization and farming practices (Dorai et al., 2001).

Yanar et al. (2011) evaluated the effects of different organic fertilizers on yield and fruit qualities of indeterminate tomato and reported satisfactory increases in the tomato yield and quality in plant treated by organic fertilizers. Similar results were reported by Suge et al. (2011) when they studied the effect of organic or inorganic fertilizers on the egg plant. Finding of Tonfack et al. (2009) are contradictory to the findings of Yanar et al. (2011) and Suge et al. (2011). Tonfack et al. (2009) studied the effect of individual or combined application of organic or mineral fertilizer on tomato plant growth and fruit $\mathrm{P}, \mathrm{K}, \mathrm{Ca}$ and $\mathrm{Na}$ contents and reported no major difference between the organic and mineral fertilizer. Further these researchers were not reported any significant effect of fertilizer application on the tomato fruit P, K, Ca and Na content.

Çolpan et al. (2013) determined the effects of potassium on the yield and yield components of tomato grown in greenhouse conditions and reported a significant effect of potassium application on the final yield of tomato crops. They also reported dose depended effect on the plant stem diameter, plant length, fruit diameter, fruit number, fruit weight, penetration resistance and sugar content. In addition, the leaf $\mathrm{N} / \mathrm{K}$ ratio also affected the tomato yield. Contrary observation was reported by Makinde et al. (2016), these researcher reported lower potassium content in the plot treated by NPK plots as compare to control but not different statistically from each other. Combined applications of mineral and organic fertilizer have higher sodium content as compared to individual application. Information regarding the effect of organic or mineral fertilizers on the Burkina Faso local verities of tomato Mongal F1 is in scarcity. The purpose of the present study is to determine the influence of organic and mineral fertilizers on the physical, chemical and biochemical characteristics of the variety of tomato Mongal F1 at different fruit ripping stages.

\section{Materials and Methods}

This experiment was conducted in the greenhouse of the National Research Center $\left(12^{\circ} 25^{\prime} \mathrm{N}, 1^{\circ} 29^{\prime} \mathrm{W}\right)$ in Burkina Faso. The site was flat, with an elevation of $435 \mathrm{~m}$ above sea level (IGB, 2014).

\subsection{Plant Materials}

Plant materials used in this study was the local variety of tomato var., Mongal F1 which was obtained from INRA (France). This variety was adapted for the dry and hot weather in Burkina Faso. It is also resistant to nematodes and some bacterial and fungal diseases (Aïssa et al., 2014). The organic fertilizer used in this study was well-decomposed livestock manure and the mineral fertilizers were N-P-K (23-14-23).

\subsection{Experimental design and studied factors}

Study was conducted in factorial randomized block design and each treatment was replicated four times. Farming operations were carried out by following the user manual instructions proposed for the variety. Two factors studied in this study were type of fertilizer and harvesting period. Effect of three sources of fertilizers viz. Organic Fertilization (OF); Mineral Fertilization (MF) and Control (C) in combination with three harvesting periods i.e. R1 (79 DAP- Days After Planting), R2 (85 DAP) R3 (89 DAP) were studied. Nine factorial combinations which were formulated in this study are C/R1, C/R2, C/R3, OF/R1, OF/R2, OF/R3, MF/R1, MF/R2, and MF/R3. Spacing between blocks was $2.5 \mathrm{~m}$ and elementary plots were $1.5 \mathrm{~m}$ apart. Each plot consisted of 4 rows of $3 \mathrm{~m}$ in length. Spacing between adjacent rows was $0.8 \mathrm{~m}$ and plants within each row were $0.5 \mathrm{~m}$ apart. Two border lines were planted on both sides in each plot to reduce border effects. Effect of these factors was studied on the physiological maturity, chemical and biochemical characteristics of the tomato fruits.

\subsection{Physical and Chemical analysis}

2.3.1 Determination of dry matter, $\mathrm{pH}$, total ash content and titratable acidity

The dry matter is determined by differential weighing before and after heating at $70^{\circ} \mathrm{C}$ in the oven by following the method of NF VO3-707 (2000). Measurements of tomato purees $\mathrm{pH}$ were carried out by pH-meter (HI 8520, Hanna Instruments, France). The ashes were obtained according to the International Standard IS0 2171 (2007), by differential weighing of samples before and after drying. The ash content 
(mineral) is estimated by incineration in an oven at $550^{\circ} \mathrm{C}$ so as to obtain all of the cations in the form of carbonate or other anhydrous inorganic salts. The titratable acidity is the content of organic and inorganic acids, determined by titration according the European Standard EN 12147 of December (1996) and NF V 05-101, January (1974). The principle of the method is based on potentiometric titration of an aqueous solution of tomato purees with sodium.

\subsubsection{Biochemical analysis}

\subsubsection{Determination of total lipids}

Total fat content was determined by Soxhlet extraction method by using hexane as extraction solvent by following the guide line proposed by International Standard ISO 659 (1998)

\subsubsection{Determination of total sugars}

Total sugars were assayed by sulfuric orcinol according to the method described by Montreuil \& Spik (1969).

\subsubsection{Determination of total protein}

Total proteins of tomato purees were measured by the differential method according to the formula below.

Protein content $=100-(\%$ humidity $+\%$ ash $+\%$ fats

$$
+\% \text { sugar) }
$$

\subsubsection{Determination of energy value}

The theoretical energy value is calculated using the coefficients of Merrill, adopted by the Southgate \& Durnin (1970). With P, C, L, the respective percentages of dry weight of protein, carbohydrates and lipids. The calorific value of the sample is obtained as follows:

Energy value $(\mathrm{kcal} / 100 \mathrm{~g} \mathrm{FT})=\mathrm{P}$ x $4 \mathrm{kcal}+\mathrm{C}$ x $4 \mathrm{kcal}+\mathrm{L}$ x 9 kcal

2.4 Statistical analysis

The data were analyzed by factor analysis of variance (ANOVA) with repetitions and the means were separated using Fischer's test at $\mathrm{P}=0.05$. The statistical analysis was performed using XLSTAT software version 7.5.2.

\section{Results and Discussion}

3.1 Effect of fertilizers application on various physical parameters of tomato var. Mongal F1

\section{$3.1 .1 \mathrm{pH}$}

All the studied samples are showing $\mathrm{pH}$ between 4.15 and 4.30 (Figure 1). These values are similar to those reported by Aoun et al. (2013) who reported $\mathrm{pH}$ value between 4.19 and 4.45 in 16 tomato varieties. Further, it was reported that $\mathrm{pH}$ values of organic fertilizer are higher than those of mineral fertilization. Acidic $\mathrm{pH}$ of tomatoes samples doesn't promote the development of some bacteria but is appropriate for the development of fungal flora (Reynes et al., 1994). The potential of hydrogen is one of the variables used to characterize the middle properties. Its value is correlated to kinetic laws of reactions, the organoleptic qualities of products or enzymatic activities (Boukhiar, 2009). Indeed, this pH level significantly reduces the rate and range of micro-organisms which can promote on the product. Only acidophil microorganisms, acetic bacteria and lactobacilli can grow, but not coliformas Escherichia coli (Messaouda, 2013).

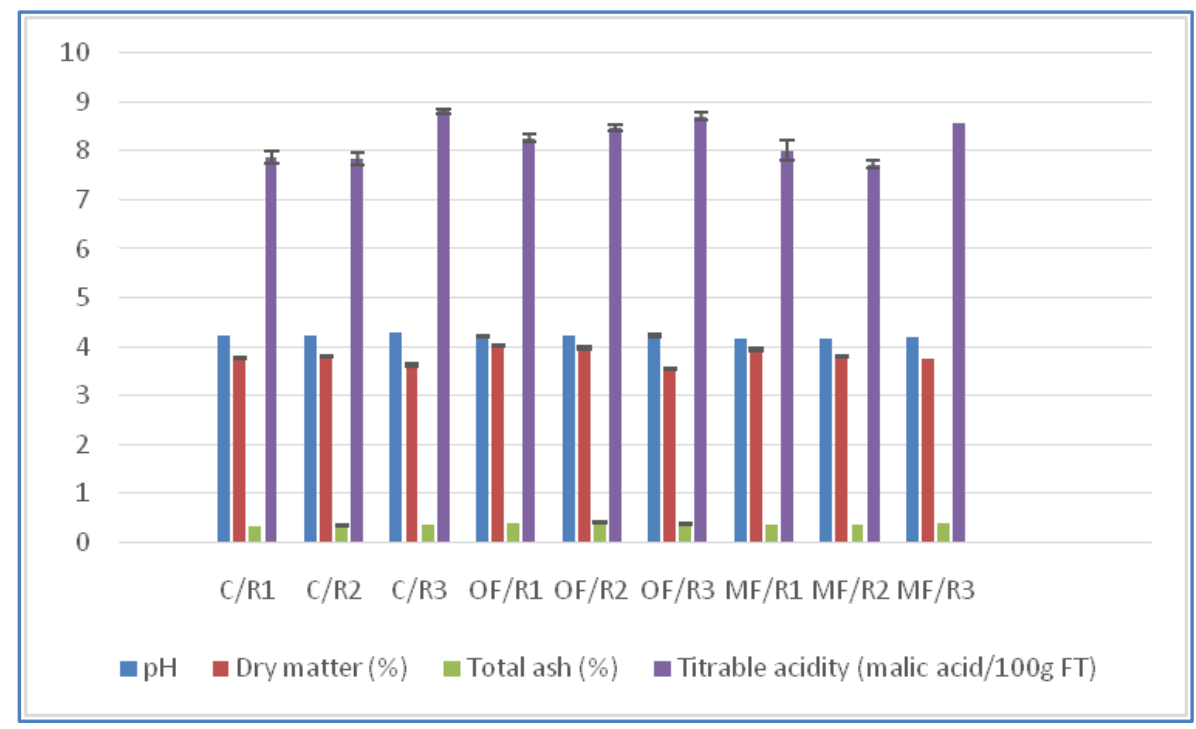

Figure 1 Effect of organic and mineral fertilizer on $\mathrm{pH}$, dry matter, total ash and Titrable acidity of tomato var. Mongal F1 
3.1.2 Dry matter content

Dry matter content was reported between $3.63 \%$ and $4.54 \%$ of the fresh one and this value was reported higher in the plant fertilized by organic manure as compared to the plant fertilized by mineral fertilizer and the control (Fig 1). Dry matter values reported in this study are lower than the findings of Messaouda (2013) those have reported $5.74 \%$ of fresh material. This slight difference could be due to the difference in the analysis method or in tomato varieties.

\subsubsection{Ash content}

No significant difference was reported in the ash contents of various treatments and this parameter varies from $0.33 \%$ to $0.39 \%$ fresh weight treatment (Fig 1). Like other two parameters, ash contents of samples fertilized by organic fertilizer are higher to those which are fertilized by mineral fertilizer for all the three harvests. This result could be explained by a greater variety of nutrients of organic manure available for plant than mineral fertilizer. The values of the ash content of the present study are lower than those reported by the USDA (2007), which is $0.5 \%$ FT. This difference is probably related to factors such as the variety of tomato used and farming practices.

\subsubsection{Titratable acidity}

Value of titratable acidity varies from 7.72 to $8.81 \mathrm{~g} / 100 \mathrm{~g}$ fresh material and it was reported higher in the plant treated by organic fertilizer and this value was higher for all the plant treated by organic compounds as compared to the plant treated by mineral fertilizers and control for all the 3 harvests (Fig 1). The values of the titratable acidity of this study are higher than the value reported by Messaouda (2013) who reported $5.74 \mathrm{~g} / 100 \mathrm{~g}$ found in the dried tomato. This difference could be explained by the difference in tomato variety used, but also the fact that the author used powder processed tomatoes.

\subsection{Biochemical characteristics}

\subsubsection{Fats}

Lipids value for plant treated by organic and mineral fertilizer are varies between 0.24 and $0.31 \%$ FT and the plant fertilized by organic manure have higher fats values than the plant fertilized with mineral fertilizer and control (Fig 2). Ripping has a positive effect on the accumulation of fats for both mineral and organic fertilizers. The values of the lipid content are higher than the value found in the literature, USDA (2007) which is $0.2 \%$ FT. This variability may be justified by the difference in various parameters such as the geographical origin of samples and the variety.

\subsubsection{Total protein content}

Like fat content, value of total proteins content also varies between 0.62 and $0.73 \%$ FT (Fig 2). Further, like fat content ripping has a positive impact on the accumulation for both mineral and organic fertilizers. Protein content with mineral fertilizer is lower than the organic manure. These values are lower than those found by USDA (2007) which is $0.88 \%$ FT. This difference could be explained by the difference in variety of present study and it's origin.

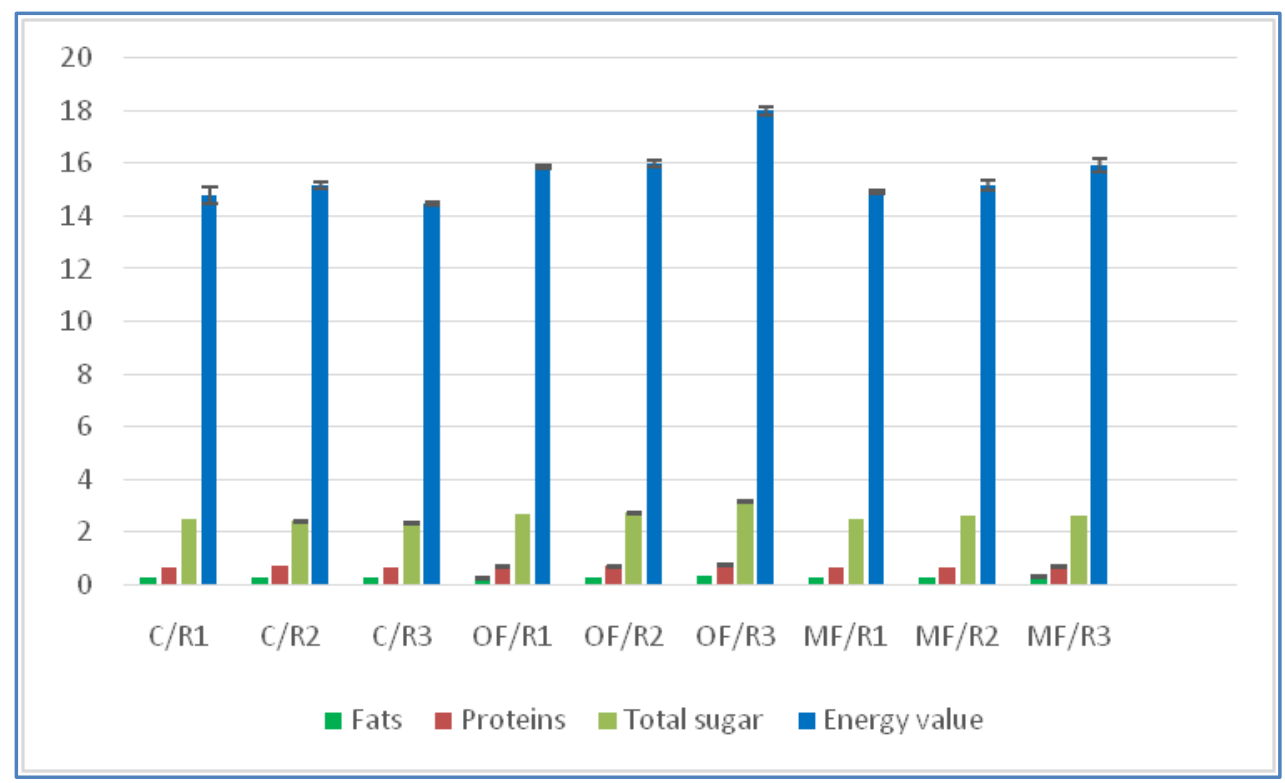

Figure 2 Effect of organic and mineral fertilizers on the levels of total lipids, total protein, total sugar and energy value 
3.2.3 Total sugar content

Value of total sugars content also varies from 2.33 to $3.14 \%$ FT and sample fertilized with mineral fertilizer shows lower total sugars content as compared to organic manure for all the three harvests. Result of study revealed that the level of total sugar increase during fruit maturation. The sugar contents of the present study are similar to those found by Messaouda (2013) and USDA (2007) which is respectively 1.38 and 3. $92 \%$. Indeed, the total sugar content is variable, and this variability may be related to the reaction of the non-enzymatic browning (Georgelis et al., 2006; Davoodia et al., 2006).

\subsubsection{Energetic value}

The energy value of tomato samples varies between 14.45 and $18.02 \mathrm{kcal} / 100 \mathrm{~g}$ of fresh material. Samples fertilized with mineral fertilizer presents lower energy values than those fertilized with organic manure. These results are similar to those found by USDA (2007) which is $18 \mathrm{kcal} / 100 \mathrm{~g}$ of fresh tomato.

\section{Conclusion}

Result of present study revealed that organic fertilizers have positive and stimulating effect on the physical, chemical and biochemical characteristics content of tomato var. Mongal F1. Moreover it was reported that mineral fertilizer does not have any significant effect on various studied parameter and it was not significantly different than the control. For parameters such as $\mathrm{pH}$, fats, acidity, protein and total sugar contents, tomatoes grown with organic manure showed higher values than those of mineral (NPK) fertilizer and fruit ripping has a positive effect on the accumulation of these compounds for both mineral and organic fertilizers.

\section{Acknowledgements}

This research project was supported by a grant from the West Africa Agricultural Productivity Program/National Center of Specialization - Fruits and Vegetables (WAAPP / NCS-FV).

\section{Conflict of interest}

Authors would hereby like to declare that there is no conflict of interests that could possibly arise.

\section{References}

Aïssa K, Ali KA, Patrick D, Boubacar D, Adamou H (2014) Les semences disponibles au Niger. Communications des sociétés GSN semences et Technisem. RECA-Niger. 3ème éd.

Aoun AB, Lechiheb B, Benyahya L, Ferchich A (2013) Evaluation of fruit quality traits of traditional varieties of tomato (Solanum lycopersicum) grown in Tunisia. African Journal of Food Science 7: 350-354. DOI: 10.5897/AJFS2013.1067.

Journal of Experimental Biology and Agricultural Sciences http://www.jebas.org
Boileau TW, Liao Z, Kim S, Lemeshow S, Erdman JW Jr, Clinton SK (2003) Prostate carcinogenesis in N-Methyl-Nnitrosourea (NMU)-testesterone treated rats fed tomato powder, lycopene or energy restricted diets. Journal of the National Cancer Institute 95: 1578-1586. DOI: http://dx.doi.org/10.1093/jnci/djg081

Boukhiar A (2009) Analyse du processus traditionnel d'obtention du vinaigre de dattes tel qu'appliqué au sud Algérie: essai d'optimisation. Mémoire de magistère, centre universitaire de Boumerdes. 45-52.

Chanforan C (2011) Stabilité de micro-constituants de la tomate (composés phénoliques, caroténoïdes, vitamines $\mathrm{C}$ et $\mathrm{E}$ ) au cours des procédés de transformation: études en systèmes modèles, mise au point d'un modèle stoechio-cinétique et validation pour l'étape unitaire de préparation de sauce tomate. Université d'Avignonet des pays de vaucluse.

Çolpan E, Zengin M, Özbahçe A (2013) The effects of potassium on the yield and fruit quality components of stick tomato. Horticulture, Environment and Biotechnology 54 : 2028. DOI:10.1007/s13580-013-0080-4.

Crawford PB, Obarzanek E, Morrison J, Sabry ZI (1994) Comparative advantage of 3-day food records over 24 recalls and 5-day food frequency validated by observation of 9 and 10 year girls. Journal of the American Dietetic Association 94 : 626-630. DOI: http://dx.doi.org/10.1016/0002-8223(94)901589.

Davoodia MG, Vijayanandb P, Kulkarnib SG, Ramanab KVR (2006) Effect of different pre-treatments and dehydration methods on quality characteristics and storage stability of tomato powder. LWT - Food Science and Technology 40:1832-1840.

DOI: http://dx.doi.org/10.1016/j.1wt.2006.12.004

Dorai M, Papadopoulos AP, Gosselin A (2001) Influence of electric conductivity management on greenhouse tomato yield and fruit quality. Agronomies 21: 367-383. DOI: http://dx.doi.org/10.1051/agro:2001130

EN 12147 (1996) Fruit and vegetable juices - Determination of titrable acidity. European Standards Publisher.

Georgelis N, Scott JW, Baldwin EA (2006) Inheritance of high sugars from tomato accession PI 270248 and environmental variation between seasons. Journal of the American Society for Horticultural Science 131:41-45.

Giovannucci E, Rimm EB, Liu Y, Stampfer MJ, Willett WC (2002) A prospective study of tomato products, lycopene, and prostate cancer risk. Journal of the National Cancer Institute 94 : 391-398. DOI: http://dx.doi.org/10.1093/jnci/94.5.391 
IGB (2014) Carte administrative des provinces du Burkina Faso. Ed. Ministère de l'Administration Territoriale.

Makinde AI, Jokanola OO, Adedeji JA, Awogbade AL, Adekunle AF (2016) Impact of Organic and Inorganic Fertilizers on the Yield, Lycopene and Some Minerals in tomato (Lycopersicum esculentum Mill) Fruit. European Journal of Agriculture and Forestry Research 4: 18-26.

Messaouda H (2013) Etude de l'activité antioxydante de la tomate séchée, Université de Hassiba Ben Bouali Chlef Algérie - Master 2 nutrition humaine.

Montreuil J, Spik G (1969) Micro dosage des sucres. Méthodes colorimétriques de dosage des sucres totaux. 85 p.Faculté des sciences Université de Lille France.

NFV 05 101(1974) Products Derived from Fruit and Vegetables - Determination Of Titrable Acidity (produits dérivés des fruits et légumes), AFNOR, Paris, France.

Norme Francaise VO3-707(2000) Céréales et produits céréaliers. Détermination de la teneur en eau. Méthode de référence pratique Pp. 8.

Norme Internationale ISO 2171 (2007) Céréales légumineuses et produits dérivés-Dosage du taux de cendres par incinération à $550^{\circ} \mathrm{C}$ Pp. 6.

Norme Internationale ISO 659 (1998) Grains oléagineusesDétermination de la teneur en huile (Méthode de référence) Pp. 13.

Oguntibeju OO, Truter EJ, Esterhuyse AJ (2013) The Role of Fruit and Vegetable Consumption in Human Health and Disease Prevention. Diabetes Mellithus - Insight and Perspectives 117 - 130. DOI: http://dx.doi.org/10.5772/50109

Reynes M, Bouabidi H, Piombo G, Risterucci AM (1994) Caractérisation des principales variétés de dattes cultivée dans la région du djérid en tunisie. Fruits 49 : 289-298.
Southgate DAT, Durnin JVGA (1970) Calorie conversion factors - An experimental reassessment of the factors used in the calculation of the energy value of human diets. British Journal of Nutrition 24: 517-535.

Suge JK, Omunyin ME, Omami EN (2011) Effect of organic and inorganic sources of fertilizer on growth, yield and fruit quality of eggplant (Solanum melongena L). Archives of Applied Science Research $3: 470-479$

Tohill BC, Seymour J, Serdula M, Kettel-Khan L, Rolls BJ (2004) What epidemiologic studies tell us about the relationship between fruit and vegetable consumption and body weight. Nutrition Reviews 62: 365-374. DOI: http://dx.doi.org/10.1301/nr.2004.oct.365-374

Tonfack LB, Bernadac A, Youmbi E, Mbouapouognigni VP, Ngueguim M, Akoa A (2009) Impact of organic and inorganic fertilizers on tomato vigor, yield and fruit composition under tropical andosol soil conditions. Fruits $64: 167-177$. DOI: 10.1051/fruits/2009012.

USDA/CNPP (2007) USDA national nutrient database for standard reference US agricultural research service available on

http://www.nal.usda.gov/fnic/foodcomp/Data/SR16/reports/sr1 6fg11.pdf access on May, 2015.

Van Duyn MA, Pivonka E, (2000) Overview of the health benefits of fruit and vegetable consumption for the dietetics professional: selected literature. Journal of the Academy of Nutrition and Dietetic 100 : 1511-1521. DOI: http://dx.doi.org/10.1016/S0002-8223(00)00420-X.

Wargovich MJ (2000) Anti-cancer properties of fruits and vegetables. HortScience 35: 573-575.

Yanar D, Geboloğlu N, Yanar Y, Aydin M, Çakmak P (2011) Effect of different organic fertilizers on yield and fruit quality of indeterminate tomato (Lycopersicon esculentum). Scientific Research and Essays 6 : 3623-3628. DOI: 10.5897/SRE10.1083. 